\title{
The Usefulness of Regulatory Capital for Investors' Judgments in the Basel 3 Framework
}

\author{
Alessandro Mechelli ${ }^{1}$, Vincenzo Sforza ${ }^{1}$, Alessandra Stefanoni ${ }^{1} \&$ Riccardo Cimini ${ }^{1}$ \\ ${ }^{1}$ University of Tuscia, Viterbo, Italy \\ Correspondence: Riccardo Cimini, Department of Economics, Engineering, Society and Business Organization, \\ University of Tuscia, Viterbo, Italy. E-mail: rcimini@unitus.it
}

Received: February 1, 2018

doi:10.5539/ijbm.v13n6p72

\begin{abstract}
Value relevance studies assess how well accounting amounts reflect the market information that investors use for their economic decisions. Analysing a sample of 90 banks listed in 24 European stock markets, this study uses a price model (Ohlson, 1995) and provides evidence that a risk-sensitive metric like regulatory capital is more useful for investors' decisions than book value of equity and that investors price the parts of regulatory capital that are devoted ideally to absorb losses differently due to the different risks taken. In particular, the part devoted to absorb losses due to credit risk is priced higher than the parts devoted to absorb other risks (e.g. market risks, operational risk). According to our evidence, this is due to the business model of the entities analysed, which are mostly retail and wholesale banks with significant credit exposure to clients and other banks. The paper adds to the literature and has implications for regulators and standard setters showing that the assessment and disclosure of regulatory capital not only strengthens the soundness and the stability of the international banking system (Basle Committee on banking supervision, 1988), but provides to investors useful information for their future investment strategies.
\end{abstract}

Keywords: market valuation, value relevance, regulatory capital, book value, risk profile, Basel 3.

\section{Introduction}

The objective of this paper is to compare and contrast the value relevance of own funds (i.e. regulatory capital), which is a measure of capital calculated according to the requirements of the third international accords of Basel, with that of book value of equity calculated according to the international accounting standards of the International Accounting Standards Board (IASB). In addition, the paper aims at assessing and comparing the value relevance of the different parts of regulatory capital that are devoted ideally to absorb losses due to the different risks taken.

The motivation of the research is the central role in the banking sector of capital configurations that led regulators to require the disclosure of two measures of capital widely different from each other in several aspects. The first is the book value of equity, which is, according to the IASB Conceptual Framework, the residual interest in the assets of the entity after deducting all its liabilities (IASB Conceptual Framework for financial reporting, 2010, § $4.4 \mathrm{c}$ ). The second is the regulatory capital which, compared with book value of equity, is a risk-sensitive metric devoted to absorb losses due to its risk profile. Financial entities must calculate this in compliance with the Basel Committee standards, issued to strengthen the soundness and the stability of the international banking system and to diminish an existing source of competitive inequality among international banks (Basle Committee on banking supervision, 1988).

Our hypotheses are that regulatory capital is more value relevant than book value of equity and that investors price the parts of regulatory capital devoted to absorb losses differently due to the entities' risk profile.

To test our hypotheses, the paper analyses a sample of 90 financial entities listed in the market of 24 European countries over 2014-2015. Research findings validate the hypothesis that regulatory capital is more value relevant than book value of equity and that investors price the parts of regulatory capital devoted to absorb losses differently in relation to the different risks taken. The presence in the sample analysed of banks whose business model is mostly wholesale- and retail-oriented with large exposure to credit risk towards other banks or clients leads investors to price the part devoted to absorb losses due to the credit risk higher than all the other parts. 
These results contribute to the literature for twofold. First, the paper provides evidence that regulatory capital continues to be more value relevant than book value of equity under the new rules of the third accord of Basel, validating the results of Mechelli et al. (2015) who investigate its explanatory power under the rules of the second accord. Second, the paper fills the gap resulting from the absence of papers that investigate the usefulness for investors' decisions of the single parts of regulatory capital devoted to absorb losses due to the risk profile of the bank. In fact, the study of the value relevance of the single parts of regulatory capital offers insight in the unexplored field regarding the usefulness of risk exposures for investors' strategies. So, despite the concern that the Basel rules introduced the regulatory capital arbitrage theory (Jones, 2000) or the thesis that the Basel accords produced an enormous moral hazard in the pillar 1 capital rules (Blundell-Wignall et al., 2013), this paper supports the arguments to provide detailed information about the risks and the regulatory capital in annual reports to support investors' decisions.

For these reasons, the paper has implications for standard setters that should introduce the mandatory disclosure of regulatory capital and of the parts devoted to absorb the single risks in the annual report because they are useful for investors' strategies.

The paper is composed by six sections. After the introduction, the second section references the literature and provides argument that support our research hypotheses. In the third section, the research protocol is described. The fourth section is dedicated to the sample selection strategy and to descriptive statistics, while in the fifth section one can find the research results. In the last section, there are the conclusions of the paper with its limitations and its possible future developments.

\section{Literature Review and Hypothesis Development}

In the last century, the debate on capital adequacy in relation to the risk appetite of financial entities has become significantly prominent for academics, policy makers and regulators. Financial crises and consequent bankruptcies have reinforced the focus on such themes, sparking a heated debate in the literature about the pros and cons of an adequate measure of capital capable of absorbing losses due to the risk profile of financial entities.

Scholars who doubt the usefulness of the total regulatory capital argue that it can be affected by arbitrage phenomena. These studies suggest that the risk-weighting system can be easily manipulated and support the "regulatory capital arbitrage" theory, that is, the possibility of reducing regulatory capital without a reduction in risks (Jones, 2000). Blundell-Wignall et al. (2013) argue that Basel 2 introduced an enormous moral hazard to the pillar 1 capital rules for large complex banks by letting them use their own internal risk models to determine the riskiness of assets to which risk weighting would apply (Blundell-Wignall et al., 2013, p. 3). Concerns about the rating system lead Cantor (2001) to discuss how bank regulators can use external ratings in ways that mitigate the adverse incentives created by the resulting regulatory demand for rating agency services. This is intended to mitigate the adverse effects (e.g. rating shopping, drop of rating agency independence and of incentives to innovate and improve the quality of ratings) that flow from the use of ratings in regulation (Cantor, 2001, p. 73).

Despite these notes of scepticism, several scholars support the thesis that regulatory capital, thanks to its inherent property to be a risk-sensitive metric, can help investors predict future cash flow. In this sense, Huang (2005) highlights the importance of capital adequacy ratios to predict subsequent bank risk. By analysing a sample of Taiwanese listed banks during 1998-2002, this scholar finds results suggesting that capital ratios can predict subsequent bank risk and that the risk-sensitive capital ratios are more informative indicators of bank solvency than the traditional capital ratio based only on the balance sheet (Huang, 2005, p. 15). Regulatory capital's capability to reflect the underlying economic value of the firm is also argued by Antonini et al. (2011), who theorize that regulatory capital is more useful for investors because it takes into account both measurable and non-measurable risks. Its higher usefulness is also explained by regulatory capital's capability to limit bank risk taking, as Demirguc-Kunt et al. (2013) demonstrate. In their paper, these scholars evaluate the effectiveness of current regulations and test existing theories that motivate the use of capital regulation to curb bank risk taking. Using a multi-country panel of banks during Q12005-Q12009, the authors also find that a more positive association with subsequent stock returns is stronger for higher quality capital in the form of Tier 1 leverage and tangible common equity (Demirguc-Kunt et al., 2013, p. 1162). More recently, in the same vein, focusing on the second accord of Basel, Mechelli et al. (2015) show that regulatory capital is more value relevant than book value of equity for investors' strategies.

As far we are concerned, several arguments lead us to hypothesise that investors also price regulatory capital higher than book value of equity under the third Accord of Basel, validating results of Mechelli et al. (2015) who 
investigate its explanatory power under the rules of the second accord.

A first reason regards the nature of regulatory capital, which is a risk-sensitive measure that plays a central role in assessment of the ratios established by the Basel rules to evaluate the capital adequacy of financial entities (Huang, 2005). These ratios provide insight to investors about the future earnings and cash flow in case the ratio is either close to or far from the thresholds. Actually, ratios that are very close to the traditional levels required by the Basel standards or to the additional requirement requested to the single banks should create doubt in investors about the future stability of the financial institutions and lead them to predict a worsening of economic conditions because of the production of both expected and unexpected losses. Otherwise, ratios that are higher than the thresholds validate the investment strategies and facilitate the prediction of future earnings and cash flow that will not be eroded by losses produced by the bank's undercapitalization. In both these cases, the regulatory capital reflects better than book value of equity the underlying economic value of the firm and helps investors predict future cash flows. The central role of regulatory capital in assessment of the capital adequacy ratio leads us to consider it risk sensitive to the extent that it must increase or decrease based on the risks taken by the banks to respect the capital adequacy requirements.

A second reason takes into consideration that some items that negatively affect the value relevance of accounting amounts are included in book value and excluded, according to the Basel requirements, from regulatory capital. An example of these items are intangible assets that according to several papers (e.g., Lev and Zarowin, 1999) reduce the value relevance of accounting amounts.

A third reason that explains the higher value relevance of regulatory capital with respect to book value of equity is grounded in the value relevance studies. In this regard, the greater value relevance of the total regulatory capital with respect to book value of equity is due to the role of equity in the price models. According to the foundational works of Penman (1992) and Ohlson (1995), book value of equity is a value-relevant factor that proxies for expected future normal earnings or, using similar words, as we can read in Collins et al. (1999, p. 58), the value relevance of equity book value stems from its role as a proxy for expected future normal earnings. Accordingly, among different measures of capital, the most persistent one should be the most value relevant due to its major capability to predict the expected future normal earnings. Comparing the total regulatory capital and the book value of equity, regulatory capital should be more persistent (less transitory) than book value of equity and so more value relevant because of its major capability to predict the expected future normal earnings. This is because the prudential filters reduce the volatility of the International Financial Reporting Standards (IFRS) accounting policies and eliminate transitory components (Masera and Mazzoni, 2012, p. 21).

All these considerations lead us to formulate the following hypothesis:

\section{$H_{1}$ : Under the third Basel accord, regulatory capital is more value relevant than book value of equity.}

To test whether investors price in the same way the different parts of regulatory capital devoted to absorb losses associated with the entity's risk profile, we start from the consideration that, in both the literature and the regulatory setting, the risk profile of financial entities is strictly related to their business model that, in turn, influences the performance of financial entities. For instance, the relationship among risks, performance and business models is clear to the Financial Stability Board (2013), which states that the risk appetite changes according to the different business models. In the same regulatory setting, the Capital Requirements Directive (CRD) 2013/36/EU states that risk-taking processes (CRD articles 74 and 76) and the performance measures (CRD article 76) differ in financial entities depending on their business models.

In the literature, Larcker and Tayan $(2011$, p. 14) argue that the risks facing an organization are comprehensive and touch all aspects of its activities. Ayadi et al. (2012, p. 26) try to identify such activities for financial entities, detecting four different kinds of business models within the European Union (EU). They are investment banks, whose activity is mainly based on trading and derivatives; retail-focused banks which use customer deposits as a primary source of funding and provide predominantly customer loans; retail-diversified banks which provide their domestic and international clients with a range of retail, investment and insurance products and wholesale banks which are active in wholesale and interbank markets with a focus on domestic business. The risk profile is a key factor used to differentiate the banks' business models. In particular, banks that rely more on non-stable forms of funding and risky investments, such as wholesale and investment banks, tend to face greater estimated default risks and lower liquidity. Retail-focused banks face comparable default risks, although these risks appear to be well shielded by relatively strong capital levels and limited liquidity mismatch risks, at least on average. The retail-diversified banking model does well under most measures, with low default risks, an average level of capitalization and moderate liquidity risks (Ayadi et al., 2012, p. 29). Analysing 505 banks from 30 European countries over 1998-2013, Mergaerts and Vennet (2016) find that business models determine not only banks' risk 
profile but also their performance.

The presence of different business models of financial entities in the EU (Ayadi et al., 2012) should explain differences in the magnitude of regulatory capital parts devoted to absorb losses due to the risk profile of financial entities. The part of regulatory capital devoted to absorb losses due to credit risk should be higher in retail and wholesale banks than in investment banks because of high credit exposure towards customers and other banks. The presence in the EU of different business models should also explain the different value relevance of the single parts of regulatory capital due to the strict relationship between the business model, risk profile and performance. Because value creation and performance of retail and wholesale banks are negatively affected, more than others, by the credit risk, in these banks investors should price higher than others the part of regulatory capital devoted to absorb losses due to the credit risk. In contrast, in investment banks, investors should price higher than others the part devoted to absorb losses due to the market risks that, in investment banks, are capable of compromising their performance more than other risks.

Therefore, our reasoning leads us to formulate the second research hypothesis, as follows:

$\mathrm{H}_{2}$ : The parts of regulatory capital devoted to absorb losses due to the risks taken have a different value relevance.

\section{Method}

To test the hypothesis that a risk-sensitive measure of capital is more useful than metrics that are not risk-sensitive, we use a price model (Ohlson, 1995) with undeflated variables that according to Barth and Clinch (2009) performs the best regardless the problem of scale effect. Starting from a relative value relevance study, to test our first research hypothesis, that involves the usefulness of different measures of capital to predict future cash flow, the equations that we use are the following:

$$
\begin{aligned}
& \mathrm{MV}_{\mathrm{it}}=\alpha_{0}+\alpha_{1} \mathrm{CI}_{\mathrm{it}}+\alpha_{2} \mathrm{BV}_{\mathrm{it}}+\varphi_{\mathrm{i}}+\gamma_{\mathrm{t}}+\varepsilon_{\mathrm{it}} \\
& \mathrm{MV}_{\mathrm{it}}=\alpha_{0}+\alpha_{1} \mathrm{CI}_{\mathrm{it}}+\alpha_{2} \mathrm{RC}_{\mathrm{it}}+\varphi_{\mathrm{i}}+\gamma_{\mathrm{t}}+\varepsilon_{\mathrm{it}}
\end{aligned}
$$

where,

$M V_{i t}$ is the market capitalization three months after the fiscal-year end;

$C I_{i t}$ is the comprehensive income reported by the firm i at time $t$;

$B V_{i t}$ is book value of equity reported by the firm $i$ at time $t$;

$R C_{i t}$ is the regulatory capital reported by the firm $i$ at time $t$;

$\varphi_{i}$ and $\gamma_{t}$ are the countries and the years' fixed effects.

The models regress the market capitalization on the comprehensive income and the different measures of capital. The choice to use comprehensive income as measure of earnings is to respect the clean-surplus relation that is an assumption of the Ohlson (1995) framework. The addition of dummy variables avoids biases due to missing data and is common in value relevance studies (e.g., Dedman and Stark, 2015).

To compare the value relevance of book value of equity and regulatory capital, we use the following methods adopted in the econometric and accounting literature to compare non-nested models:

- J-test: introduced by Davidson and MacKinnon (1981), the econometrics literature considers this test not only rigorous, but respect to the other methodologies useful for the same purpose and used in this paper to compare different model specifications it is considered the most powerful tool to compare non-nested models (Verbeek, 2006, p. 54). Despite of its strengthens, the J-test has been used by fewer accounting researchers (Chan and Seow, 1996; Bao and Chow, 1999; Yang et al., 2005; Mechelli and Cimini, 2013). Using the specification of the equations above presented, according to the J-test, we denote as model " $\mathrm{A}$ " equation (1) that includes between regressors also the predicted values of equation (2) and as model "B" equation (2) that includes between regressors also the predicted values of equation (1).

$$
\begin{aligned}
& \mathrm{MV}_{\mathrm{it}}=\alpha_{0}+\alpha_{1} \mathrm{CI}_{\mathrm{it}}+\alpha_{2} \mathrm{BV}_{\mathrm{it}}+\varphi_{\mathrm{i}}+\gamma_{\mathrm{t}}+\delta_{\mathrm{A}} \hat{\mathrm{Y}}_{\mathrm{B}}+\varepsilon_{\mathrm{it}} \\
& \mathrm{MV}_{\mathrm{it}}=\alpha_{0}+\alpha_{1} \mathrm{CI}_{\mathrm{it}}+\alpha_{2} \mathrm{RC}_{\mathrm{it}}+\varphi_{\mathrm{i}}+\gamma_{\mathrm{t}}+\delta_{\mathrm{B}} \hat{\mathrm{Y}}_{\mathrm{A}}+\varepsilon_{\mathrm{it}}
\end{aligned}
$$

where $\widehat{Y}_{A}$ are the predicted values of the book value model and $\widehat{Y_{B}}$ those of the regulatory capital model. 
According to the J-test, if $\delta_{\mathrm{A}}$ is statistically significant and $\delta_{\mathrm{B}}$ is not, the predicted values of model "B" add significant information to model " $\mathrm{A}$ " in predicting the dependent variable, so regulatory capital is more value relevant than book value of equity; in other words, the second model encompasses the first one. Our expectation is to find that the model with regulatory capital encompasses the model with book value of equity.

- $\quad \mathrm{R}^{2}$ comparison: extensively used by scholars to compare different model specifications (Biddle and Choi, 2006; Dhaliwal et al., 1999; Goncharov and Hodgson, 2011; Kanagaretnam et al., 2009; Lin et al., 2007), we compare the adjusted $R^{2}$ of equations (1) and (2) testing if the difference between such $R^{2}$ is statistically significant calculating the Vuong (1989) V-statistic. Our expectation is to find the $R^{2}$ of equation (2) higher and statistically different respect to that of equation (1);

- Regression coefficients and t-statistics comparison: the accounting literature uses the regression coefficients (e.g. Song et al., 2010) and the t-statistics (e.g. Kousenidis et al., 2009) as measures of value relevance of accounting amounts and comparing them scholars estimate the different weight the investors place on accounting figures. Our expectation is to find regression coefficient and t-statistic of $\mathrm{RC}_{\mathrm{it}}$ higher than regression coefficient and t-statistic of $\mathrm{BV}_{\mathrm{it}}(2)$.

To test our second research hypothesis, we decompose the regulatory capital included in equation (2) into the different parts devoted to absorb losses in relation to the different risks' exposures. The specification that we use is the following:

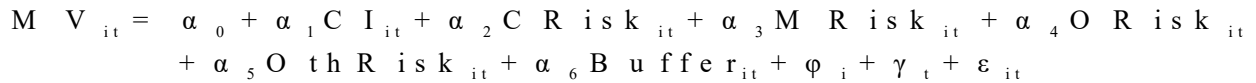

where,

CRisk $_{\text {it }}$ is the amount of regulatory capital devoted to absorb losses that arise from the credit risk;

MRisk $k_{i t}$ is the amount of regulatory capital devoted to absorb losses that arise from the market risks;

ORisk $k_{i t}$ is the amount of regulatory capital devoted to absorb losses that arise from the operational risk;

OthRisk $_{\text {it }}$ is the amount of regulatory capital devoted to absorb losses that arise from other measurable and not-measurable risks;

Buffer $_{\text {it }}$ is the residual portion of regulatory capital.

The presence in the European context of banks with different business models should lead investors to price differently the parts of regulatory capital. Therefore, our expatiation is to find a different value relevance of explicative variables included in equation (3). Value relevant parts are those whose coefficients are statistically significant at the traditional level (e.g. 5\%).

Standard errors of our equations are robust to heteroscedasticity and have been estimated according to the White (1980) procedure because of the limited number of clustered years respect to those suggested to follow the Petersen (2009) procedure.

\section{Sample Selection and Descriptive Statistics}

The sample used to compare the value relevance of book value of equity and of regulatory capital and to evaluate how investors price the exposures at the different risks number 90 financial entities that consolidated their accounts and that are listed in 24 countries of the European Union over the period 2014-2015 (180 firm-year observations). These entities comply with the IASB standards, belong to the Basel Committee and adopted the new regulatory framework introduced in the EU by the Capital Requirements Regulation (CRR) that became effective as of $1^{\text {st }}$ January 2014.

Our sample selection strategy and the geographical portrait of the financial institutions analyzed are described in Table 1. 
Table 1. Sample selection strategy and geographical portrait of the entities analysed

\begin{tabular}{lr}
\hline & entities \\
\hline No. of publicly traded financial entities from Orbis Bank Focus database & 290 \\
Less financial entities not reporting on $31^{\text {st }}$ December & 34 \\
Less financial entities that do not consolidate their accounts & 48 \\
Less entities that do not apply the Basel 3 requirements & 25 \\
Less entities with accounting variables not available over the entire period analysed & 16 \\
Less financial entities with missing data & $\underline{77}$ \\
Final sample & 90 \\
\hline
\end{tabular}

\begin{tabular}{lrrlrrlrr}
\hline Countries & $\begin{array}{r}\text { Country- } \\
\text { banks }\end{array}$ & FYO & Countries & $\begin{array}{r}\text { Country- } \\
\text { banks }\end{array}$ & FYO & Countries & $\begin{array}{r}\text { Country- } \\
\text { banks }\end{array}$ & FYO \\
\hline Austria & 6 & 12 & France & 5 & 10 & Netherland (The) & 3 & 6 \\
Belgium & 1 & 2 & Germany & 6 & 12 & Poland & 9 & 18 \\
Bulgaria & 2 & 4 & Greece & 4 & 8 & Portugal & 1 & 2 \\
Cyprus & 1 & 2 & Hungary & 1 & 2 & Slovak Rep & 2 & 4 \\
Croatia & 1 & 2 & Ireland & 2 & 4 & Spain & 6 & 12 \\
Czech Rep & 1 & 2 & Italy & 15 & 30 & Romania & 1 & 2 \\
Denmark & 7 & 14 & Latvia & 1 & 2 & Sweden & 4 & 8 \\
Finland & 1 & 2 & Malta & 2 & 4 & U.K. & 8 & 16 \\
\hline
\end{tabular}

The table suggests that moving from an initial sample of 290 financial institutions that are subject to the Basel 3 capital requirements, after exclusions, our final sample numbers 90 entities listed in 24 of the 28 countries that belong to EU. Entities not included in the sample are those not reporting on $31^{\text {st }}$ December (34), those that do not consolidate their accounts (48), those that do not apply the Basel 3 requirements due to their nature (e.g., real estate, financial advisory) (25), those whose accounting data are not available over all the period analysed (16) and those with unavailable data regarding the risks' exposure (77). The problem of missing data was mostly due to hand-collecting the portion of regulatory capital devoted to absorb losses due to the different risks exposures. In fact, while these data have been hand-collected from the consolidated annual reports or in the Pillar 3 statements, the list of financial entities and accounting amounts useful to test our hypotheses have been downloaded from the Orbis Bank Focus database.

Table 2 summarizes the main descriptive statistics (percentiles and means) of both the dependent and the independent variables used to test our hypothesis.

Table 2. Percentiles and mean of data

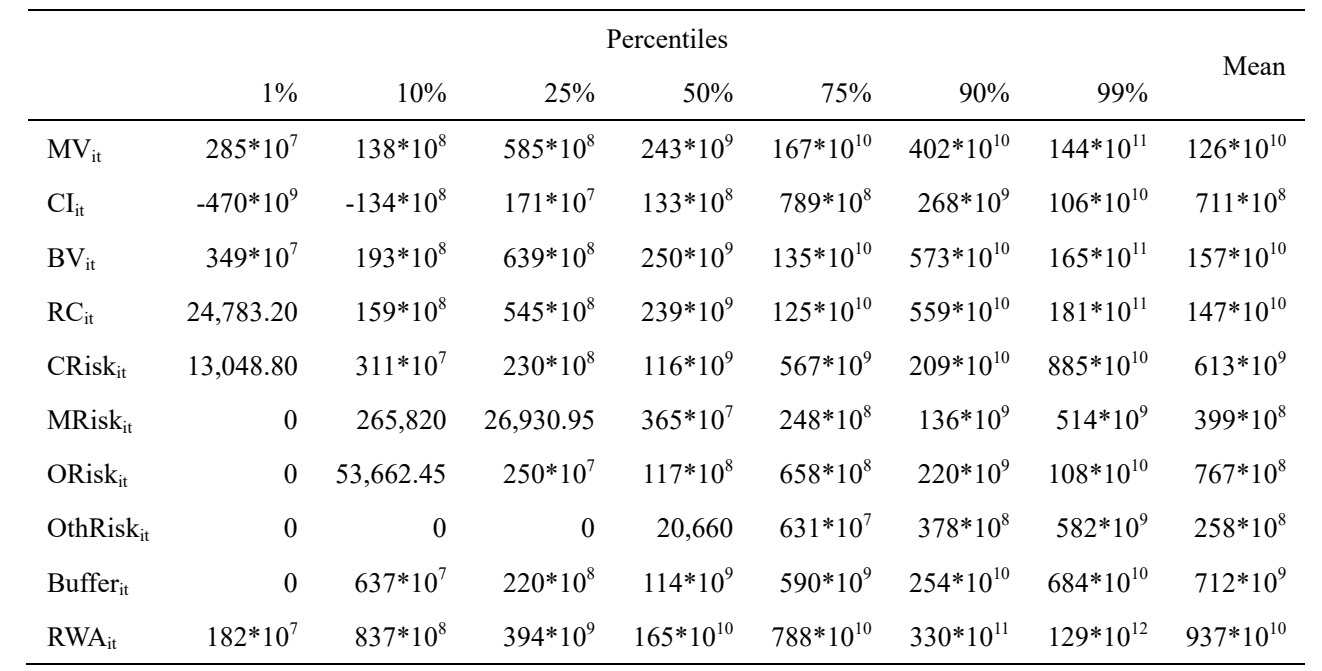

The analysis of the percentiles for book value of equity and of regulatory capital disclosed in the previous table shows that all the values observed are positive. Comparing the percentiles of the regulatory capital with those of 
book value of equity, we found that the former is higher than the latter upper to the $99^{\text {th }}$ percentile. These are the biggest banks with the highest risk appetite. According to the literature, a positive correlation exists between entity size and risk appetite (Stan et al. 2012, Elyasiani et al. 2007, De Nicolo et al. 2004). The lower values of regulatory capital respect to book value of equity under the $99^{\text {th }}$ percentile are the consequence of prudential filters and detractions that are also one motivation that makes, according to our theoretical framework, the regulatory capital more value relevant than book value of equity. Descriptive statistics provide insights about the potential losses that regulatory capital has to absorb and that are due to the different risks that banks have to face. In all the banks, there is a significant portion of regulatory capital devoted to absorb losses due to the credit risk. Also the market risk and the operational risk produce losses but their amount is by far less significant than the one of the credit risk (e.g., this is true both in case of undeflated and deflating variables by the total assets). A possible explanation is the fact that most of banks included in the sample belong to the business models of commercial and wholesale banks and that investment banks, where the market risks should be more significant, are not so common. To provide evidence to such thesis, we calculate three ratios that identify the three above mentioned business models. The first one is the total customer deposits to total assets, the second is the loans to banks to total assets and the last one is derivatives to total assets. These ratios allow identifying the commercial banks, the wholesale banks and the investment banks, respectively. Figure 1 is a contour plot that provides evidence about the presence of different business models in the sample of banks analysed.

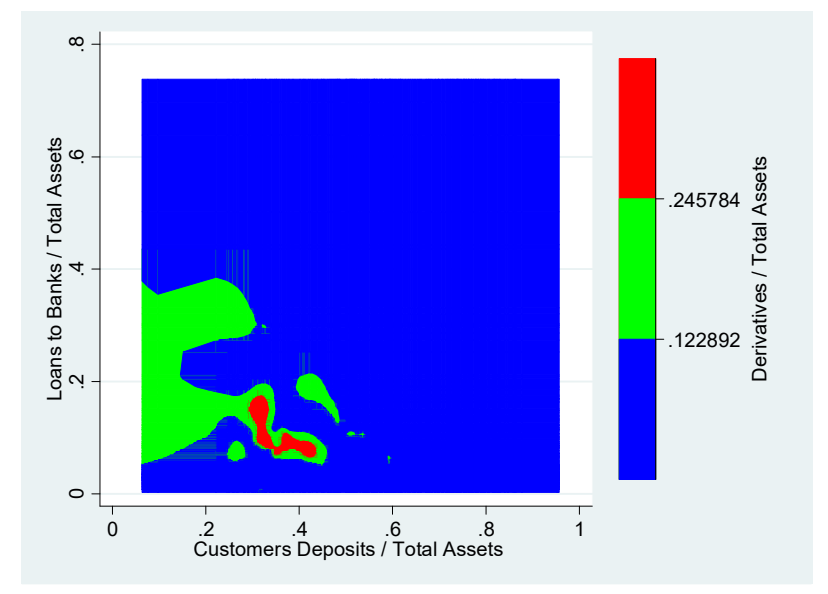

Figure 1. Business models of EU-24 financial entities

The plot has on the x-axis the customer deposits deflated by total assets, on the y-axis the loans to banks deflated by total assets and on the z-axis the derivatives scaled by total assets. The blue area that is the squares with high level of customer deposits or loans to banks denotes the commercial and the wholesale banks that traditionally have to face a high credit risk; the green and the red ones identify the investment banks where exposure to the market risks is more significant.

To conclude the comments of descriptive statistics tabulated in Table 2, the percentiles of the operational risk absorb less than the credit risk and higher than the market risk. For the other risks, they are not so significant. In fact, only $50 \%$ of the banks analysed have estimated expected and unexpected losses that mostly are due to such residual category.

To conclude, we present in Table 3 the correlation coefficients between the independent and the dependents variables used in our analysis and a multicollinerity test. 
Table 3. Correlation coefficients

\begin{tabular}{|c|c|c|c|c|c|c|c|c|c|c|}
\hline & $\mathrm{MV}_{\text {it }}$ & $\mathrm{CI}_{\mathrm{it}}$ & $\mathrm{BV}_{\text {it }}$ & $\mathrm{RC}_{\mathrm{it}}$ & CRisk $_{\text {it }}$ & MRisk $_{\text {it }}$ & ORisk $_{\text {it }}$ & OthRisk $_{\text {it }}$ & Buffer $_{\text {it }}$ & $\mathrm{RWA}_{\mathrm{it}}$ \\
\hline$M V_{i t}$ & 1.00 & & & & & & & & & \\
\hline $\mathrm{CI}_{\mathrm{it}}$ & $0.60^{* * *}$ & 1.00 & & & & & & & & \\
\hline $\mathrm{BV}_{\text {it }}$ & $0.94^{* * *}$ & $0.54^{* * *}$ & 1.00 & & & & & & & \\
\hline $\mathrm{RC}_{\mathrm{it}}$ & $0.93^{* * *}$ & $0.46^{* * *}$ & $0.97^{* * *}$ & 1.00 & & & & & & \\
\hline CRisk $_{\text {it }}$ & $0.92^{* * *}$ & $0.49^{* * *}$ & $0.94^{* * *}$ & $0.97^{* * *}$ & 1.00 & & & & & \\
\hline MRisk $_{\text {it }}$ & $0.75^{* * *}$ & $0.37^{* * *}$ & $0.84^{* * *}$ & $0.87^{* * *}$ & $0.82^{* * *}$ & 1.00 & & & & \\
\hline ORisk $_{\mathrm{it}}$ & $0.88^{* * *}$ & $0.47^{* * *}$ & $0.94^{* * *}$ & $0.95^{* * *}$ & $0.93^{* * *}$ & $0.89^{* * *}$ & 1.00 & & & \\
\hline OthRisk $_{\text {it }}$ & $0.36^{* * *}$ & $0.39^{* * *}$ & $0.35^{* * *}$ & $0.33^{* * *}$ & $0.31^{* * * *}$ & $0.26^{* * *}$ & $0.34^{* * *}$ & 1.00 & & \\
\hline Buffer $_{i t}$ & $0.89^{* * *}$ & $0.40^{* * *}$ & $0.95^{* * *}$ & $0.96^{* * *}$ & $0.89^{* * *}$ & $0.86^{* * *}$ & $0.90^{* * *}$ & $0.25^{* * *}$ & 1.00 & \\
\hline $\mathrm{RWA}_{\mathrm{it}}$ & $0.92^{* * *}$ & $0.49^{* * *}$ & $0.95^{* * *}$ & $0.98^{* * *}$ & $0.99^{* * *}$ & $0.86^{* * *}$ & $0.96^{* * *}$ & $0.34^{* * *}$ & $0.91^{* * *}$ & 1.00 \\
\hline \multicolumn{5}{|c|}{ Mean V.I.F. Equation (1) } & +4.26 & & & & & \\
\hline \multicolumn{5}{|c|}{ Mean V.I.F. Equation (2) } & +4.24 & & & & & \\
\hline \multicolumn{5}{|c|}{ Mean V.I.F. Equation (3) } & +5.17 & & & & & \\
\hline
\end{tabular}

As reported in Table 3, we find relatively high correlations between all the variables, especially between those included in equation (3). This is the reason why we tabulate the mean variance inflation factor (V.I.F.) for each equation to show that multicollinearity problems do not bias the research results. The mean V.I.F. is equal to 4.26 (equation 1), 4.24 (equation 2) and 5.17 (equation 3). Considering that there is a rule of thumb that the V.I.F. should not exceed 10 and that each variable has a V.I.F. lower than the threshold, we can consider our results not biased by multicollinearity problems.

\section{Results}

The following table shows the results achieved in the relative value relevance study, that is, comparing the value relevance of regulatory capital with that of book value of equity.

Table 4. The value relevance of $\mathrm{BV}$ and $\mathrm{RC}$

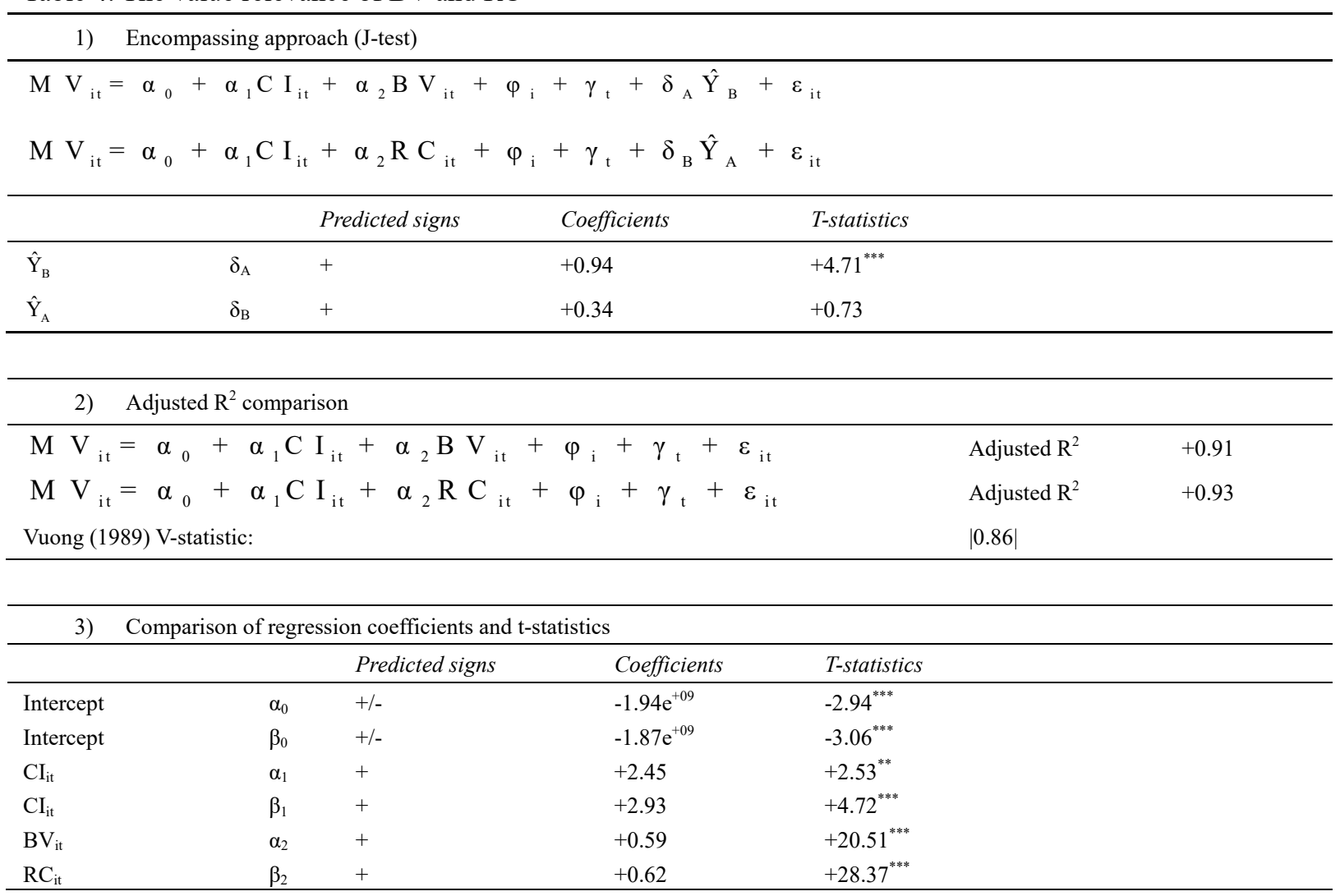

$\left({ }^{* * *}\right) 1 \%$ level of significance $-\left(^{* *}\right) 5 \%$ level of significance $-\left(^{*}\right) 10 \%$ level of significance. 
All the methodologies used to test the first research hypothesis suggest that investors place more weight on risk-sensitive measure of capital for their decisions. In fact, regulatory capital is more value relevant than book value of equity.

According to the J-test, being $\delta_{\mathrm{A}}$ statistically significant - at $1 \%$ - the predicted values of model "B" (the one in which the total regulatory capital is included) adds significant information in model " $\mathrm{A}$ " (the one in which book value of equity is included). Taking also into account that $\delta_{\mathrm{B}}$ is not statistically significant (in this case, book value of equity adds nothing to the total regulatory capital model), the total regulatory capital explains better than book value of equity the relation with the dependent variable.

Also comparing the goodness-of-fit of these two models, we find that the adjusted $\mathrm{R}^{2}$ of the equation in which the total regulatory capital is included between regressors $(0.93)$ is higher than the adjusted $\mathrm{R}^{2}$ of the equation that includes book value between the explicative variables (0.91). However, the Vuong (1989) test fails to reject the null hypothesis that the difference between $\mathrm{R}^{2}$ is not statistically significant (e.g. V-statistic $=|0.86|$ ). Actually, the adjusted $\mathrm{R}^{2}$ of total regulatory capital is not so higher than the adjusted $\mathrm{R}^{2}$ of book value of equity. This result does not worry us in the light of our findings concerning the J-test, the most robust among all the statistical tools useful to compare non-nested models (Verbeek, 2006) and of concerns regarding the use of $\mathrm{R}^{2}$ in value relevance studies. Concerns regard the use of $\mathrm{R}^{2}$ in case of a cross-sample comparison and in case of comparison of different model specifications within the same sample (e.g., like in our research). While Gu (2007) illustrates why the regression $R^{2}$ s are incomparable across samples and the general nature of this problem $(\mathrm{Gu}, 2007, \mathrm{p}$. 1073), Brown et al. (1999) and Chang (1999) show that the presence of a scale factor or heteroscedasticity in the regression variables would make the $R^{2}$ an unreliable statistic (Gu, 2007, p. 1074). According to Brown et al. (1999), $\mathrm{R}^{2}$ comparison is possible only in the return models, that they considered free from scale; Chang (1999) argues that limitations associated with the use of $\mathrm{R}^{2}$ are unavoidable, instead.

The regression coefficients and t-statistics comparison not only continues to confirm the higher value relevance of the total regulatory capital respect to book value of equity but also that both of them are statistically significant, and so value relevant, at $1 \%$ (e.g., p-value $<1 \%$ ). The regression coefficient of regulatory capital $(+0.62)$ is higher than that of book value of equity $(+0.59)$; the t-statistic of regulatory capital $(+28.37)$ is higher than that of book value of equity $(+20.51)$.

For our second research hypothesis, results are tabulated in Table 5.

Table 5. The value relevance of the different parts of RC

\begin{tabular}{|c|c|c|c|c|}
\hline FYO & 180 & & & \\
\hline \multirow[t]{2}{*}{$\mathrm{R}^{2}$} & 0.92 & & & \\
\hline & & Predicted signs & Coefficients & T-statistics \\
\hline Intercept & $\alpha_{0}$ & $+/-$ & $-1.49 \mathrm{e}^{+09}$ & $-2.48^{* * *}$ \\
\hline $\mathrm{CI}_{\mathrm{it}}$ & $\alpha_{1}$ & + & +2.39 & $+3.88^{* * *}$ \\
\hline CRisk $_{\text {it }}$ & $\alpha_{2}$ & + & +1.16 & $+5.98^{* * *}$ \\
\hline MRisk $_{\text {it }}$ & $\alpha_{3}$ & + & +0.81 & -0.20 \\
\hline ORisk $_{\text {it }}$ & $\alpha_{4}$ & + & +0.09 & +0.04 \\
\hline OthRisk $_{\text {it }}$ & $\alpha_{5}$ & + & +0.76 & +1.37 \\
\hline Buffer $_{\text {it }}$ & $\alpha_{6}$ & + & +0.13 & +0.45 \\
\hline
\end{tabular}

$\left(^{* * *}\right) 1 \%$ level of significance $-\left(^{* *}\right) 5 \%$ level of significance $-\left(^{*}\right) 10 \%$ level of significance.

Running equation (3), as expected, investors price differently the portions of regulatory capital devoted to absorb losses due to the different risks. This validates also our second research hypothesis. Among the risks, only the cluster of regulatory capital devoted to absorb the credit risk is value relevant at $1 \%$ with a regression coefficient of +1.16 and a t-statistic of +5.98 . This does not surprise us. The nature of the business model that influences the risk profile of financial entities leads investors to place more weigh on exposures at risks that, more than others, influences the performance of the entity. Because the majority of the banks analysed has a retail or wholesale business model, investors place more weight on the parts of regulatory capital devoted to absorb losses due to the exposures to the credit risk taking into account their major capability to affect the future performance of the banks. In addition, the results confirm that information relevant to the measurement of a firm's credit risk is reflected in its equity price (Demirovic and Thomas, 2007, p. 253). 


\section{Conclusion}

Risk has a key role in investment decisions. This paper has shown that investors price higher a measure of capital that is risk-sensitive with respect to an alternative measure of capital that does not take into account the risk profile of the entity. Analysing a sample of 90 banks listed in the market of 24 European countries, we provided evidence that regulatory capital is more value relevant than book value of equity and that its parts devoted to absorb losses due to the risks assumed are priced differently by investors. In particular, the part devoted to absorb losses due to the credit risk is more value relevant than the other parts that are not priced by investors. According to our reasoning, this provides insights that the business model of the entity, that both the literature and the practice consider strictly related with the risk profile of the entity, affects the weight investors place on risk-sensitive metrics.

The main contribution of this paper for the practice is that the assessment and disclosure of regulatory capital not only strengthens the soundness and the stability of the international banking system (Basle Committee on banking supervision, 1988) when public trust in regulators is often low (Löfstedt 2005), but, overall, provides to investors useful information for their future investment strategies. This is due to the nature of this configuration of capital that is influenced by the risk exposure. In addition, regulators should learn that its parts have different capability to influence the investors' decisions according to the (different) nature of the business of financial entities. For academics, this paper provides evidence that information regarding the risks' exposures, which are considered "other information" (Ohlson, 1995) not included between the accounting amounts of the price valuation model, are useful for investors' strategies.

A limitation of the research is that it involves many countries with different institutional context that we try to control by adding country dummy variables in equations we used. Another limit of this research refers to the high number of entities we have to exclude because of missing data.

There are several possibilities to develop the research. A possible extension of the paper refers to the opportunity to investigate the topic in context where banks are mostly investment banks. According to our thesis, in these banks investors should price the segment of regulatory capital devoted to absorb the market risks more than the other risks. A further possibility is to detect the timeliness of information disclosed in the regulatory capital, comparing them with the one of the book value of equity and investigating whether the single parts differ from each other also in terms of timeliness. With this regard while the higher volatility of book value could impair its value relevance as demonstrated in this paper, on the contrary it could increase its timeliness in giving useful information to investors.

\section{References}

Antonini, V., Tomasini, K., \& Zattarin, S. (2011). Il patrimonio netto e il patrimonio di vigilanza in Rutigliano M. (2011), Il bilancio della banca. Schemi, principi contabili e analisi dei rischi, Egea, Milano.

Ayadi, R., Arbak, E., \& Pieter De Groen, W. (2012). Regulation of European banks and business models: Towards a new paradigm? Centre for European Policy Studies.

Bao, B. H., \& Chow, L. (1999). The Usefulness of Earnings and Book Value for Equity Valuation in Emerging Capital Markets: Evidence from Listed Companies in the People's Republic of China. Journal of International Financial Management \& Accounting, 10(2), 85-104. https://doi.org/10.1111/1467-646X.00045

Barth, M. E., \& Clinch, G. (2009). Scale Effects in Capital Markets-Based Accounting Research. Journal of Business Finance \& Accounting, 36(3-4), 253-288. https://doi.org/10.1111/j.1468-5957.2009.02133.x

Basle Committee on Banking Supervision. (1988). International Convergence of Capital Measurement and Capital Standards.

Biddle, G., \& Choi, J. H. (2006). Is comprehensive income useful? Journal of Contemporary Accounting \&Economics, 2(1), 1-32. https://doi.org/10.1016/S1815-5669(10)70015-1

Blundell-Wignall, A., Atkinson, P., \& Roulet, C. (2013). Bank business models and the Basel system: complexity and interconnectedness. Financial Market Trends, 2, 1-29.

Brown, S., Lo, K., \& Lys, T. (1999). Use of $\mathrm{R}^{2}$ in accounting research: Measuring changes in value relevance over the last four decades. Journal of Accounting and Economics, 28(2), 83-115. https://doi.org/10.1016/S0165-4101(99)00023-3

Cantor, R. (2001). Moody's investors service response to the consultative paper issued by the Basel Committee on Bank Supervision "A new capital adequacy framework. Journal of Banking \& Finance, 25(1), 171-185. 
https://doi.org/10.1016/S0378-4266(00)00121-7

Chan, K., \& Seow, G. (1996). The Association between Stock Returns and Foreign GAAP Earnings Versus Earnings Adjusted to U.S. GAAP. Journal of Accounting and Economics, 21, 139-158. https://doi.org/10.1016/0165-4101(95)00405-X

Chang, J. (1999). The Decline in Value Relevance of Earnings and Book Values. Working paper, The Wharton School, University of Pennsylvania.

Collins, D. W., Pincus, M., \& Xie, W. (1999). Equity valuation and negative earnings: The role of book value of equity. The Accounting Review, 74(1), 29-61. https://doi.org/10.2308/accr.1999.74.1.29

Davidson, R., \& MacKinnon, J. G. (1981). Several tests for Model Specification in the Presence of Alternative Hypotheses. Econometrica, 49(3), 781-793. https://doi.org/10.2307/1911522

De Nicolo, G., Bartholomew, P., Zaman, J., \& Zephirin, M. (2004). Bank consolidation, internationalization and conglomeration: Trends and implications for financial risk. Financial Markets, Institutions and Instruments, 13(4), 173-217. https://doi.org/10.1111/j.0963-8008.2004.00076.x

Dedman, E., Jiang, W., \& Stark, A. (2015). The value relevance and information content of cash and stock dividends in China. The European Journal of Finance, 1-29. https://doi.org/10.1080/1351847X.2014.996658

Demirguc-Kunt, A., Detragiache, E., \& Merrouche, O. (2013). Bank capital: lesson from the financial crisis. Journal of Money, Credit and Banking, 45(6), 1147-1164. https://doi.org/10.1111/jmcb.12047

Demirovic, A., \& Thomas, D. C. (2007). The relevance of accounting data in the measurement of credit risk. The European Journal of Finance, 13(3), 253-268. https://doi.org/10.1080/13518470601025177

Dhaliwal, D., Subramanyam, K. R., \& Trezevant, R. (1999). Is comprehensive income superior to net income as a measure of firm performance. Journal of Accounting and Economics, 26(1-3), 43-67. https://doi.org/10.1016/S0165-4101(98)00033-0

Directive. (2013). EU of the European Parliament and of the Council on access to the activity of credit institutions and the prudential supervision of credit institutions and investment firms.

Elyasiani, E., Mansur, I., \& Pagano, M. (2007). Convergence and risk-return linkages across financial services firms, Journal of Banking and Finance, 31, 1167-1190. https://doi.org/10.1016/j.jbankfin.2006.10.006

Financial Stability Board. (2013). Principle for an Effective Risk Appetite Framework.

Goncharov, I., \& Hodgson, A. (2011). Measuring and Reporting Income in Europe. Journal of Accounting Research, 10(1), 27-59. https://doi.org/10.2308/jiar.2011.10.1.27

$\mathrm{Gu}, \mathrm{Z}$. (2007). Across-sample incomparability of $\mathrm{R}^{2}$ and Additional Evidence on Value Relevance Changes over Time. Journal of Business Finance \& Accounting, 34(7-8), 1073-1098. https://doi.org/10.1111/j.1468-5957.2007.02044.x

Huang, D. F. (2005). The predictive power of capital adequacy ratios on bank risk. Journal of Contemporary Accounting, 6(1), 1-22.

International Accounting Standard Board. (2010). IASB Conceptual Framework for financial reporting.

Jones, D. (2000). Emerging problems with the Balsel Capital Accord: regulatory capital arbitrage and related issue, Journal of Banking and Finance, 24, 35-58. https://doi.org/10.1016/S0378-4266(99)00052-7

Kanagaretnam, K., Mathieu, R., \& Shehata, M. (2009). Usefulness of comprehensive income reporting in Canada, Journal of Accounting and Public Policy, 28(4), 349-365. https://doi.org/10.1016/j.jaccpubpol.2009.06.004

Kousenidis, D. V., Ladas, A. C., \& Negakis, C. I. (2009). Value relevance of conservative and non-conservative accounting information, International Journal of Accounting, 44(3), 219-238. https://doi.org/10.1016/j.intacc.2009.06.006

Larcker, D. F., \& Tayan, B. (2011). Organizational strategy, Business models and Risk management. Stanford Graduate School of Business.

Lev, B., \& Zarowin, P. (1999). The boundaries of financial reporting and how to extend them. Journal of Accounting research, 37(2), 353-385. https://doi.org/10.2307/2491413

Lin, S. W., Ramond, O., \& Casta, J.F. (2007). Value Relevance of Comprehensive Income and Its Components: 
Evidence from Major European Capital Markets. Open access publications from Université Paris-Dauphine.

Löfstedt, R. E. (2005). Risk Management in Post Trust Societies. Basingstoke: Palgrave MacMillan.

Masera, F., \& Mazzoni, G. (2012). Basilea III. Il nuovo sistema di regole bancarie dopo la grande crisi: Il nuovo sistema di regole bancarie dopo la grande crisi. FrancoAngeli.

Mechelli, A., \& Cimini, R. (2013). Assessing value relevance of comprehensive income in European banks and other financial institutions. Financial reporting, 1, 13-41. https://doi.org/10.3280/FR2013-001003

Mechelli, A., Cimini, R., \& Mazzocchetti, F. (2015). Is regulatory capital more value relevant than book value of equity? A cross-country analysis, Applied Economics Letters, 22(11), 900-903. https://doi.org/10.1080/13504851.2014.985368

Mergaerts, F., \& Vander Vennet, R. (2016). Business models and bank performance: A long-term perspective, Journal of Financial Stability, 22, 57-75. https://doi.org/10.1016/j.jfs.2015.12.002

Ohlson, J. A. (1995). Earnings, book values, and dividends in equity valuation. Contemporary Accounting Research, 11, 661-688. https://doi.org/10.1111/j.1911-3846.1995.tb00461.x

Penman, S. (1992). Return to fundamentals. Journal of Accounting, Auditing and Finance, 7, 465-483. https://doi.org/10.1177/0148558X9200700403

Petersen, M. (2009). Estimating standard errors in finance panel data sets: comparing approaches, Review of Financial Studies, 22(1), 435-480. http://www.jstor.org/stable/40056916

Song, C. J., Thomas, W. B., \& Yi, H. (2010). Value relevance of FAS No. 157 Fair Value Hierarchy Information and the Impact of Corporate Governance Mechanisms. The Accounting Review, 85(4), 1375-1410. Retrieved from http://www.jstor.org/stable/20744163

Stan, M., \& McIntyre, M. L. (2012). Too big to fail? Size and risk in banking. Academy of Banking Studies Journal, 11(2), 11-21.

Verbeek, M. (2006). Econometria. Zanichelli Editore, Bologna.

Vuong, Q. (1989). Likelihood ratio tests for model selection and non-nested hypothesis. Econometrica, 57, 307-333. https://doi.org/10.2307/1912557

White, H. (1980). A heteroskedasticity-consistent covariance matrix estimator and a direct test for heteroskedasticity. Econometrica, 48, 817-838. https://doi.org/10.2307/1912934

Yang, Z., Rohrbach, K., \& Chen, S. (2005). The Impact of Standard Setting on Relevance and Reliability of Accounting Information: Lower of Cost or Market Accounting Reforms in China. Journal of International Financial Management and Accounting, 16(3), 194-228. https://doi.org/10.1111/j.1467-646X.2005.00117.x

\section{Copyrights}

Copyright for this article is retained by the author(s), with first publication rights granted to the journal.

This is an open-access article distributed under the terms and conditions of the Creative Commons Attribution license (http://creativecommons.org/licenses/by/4.0/). 